\title{
Comparison of Economic Institutions in China and India
}

\subsection{Introduction}

Global business strategies must conform to business environments in target countries and regions. As repeatedly expressed herein, while the world is becoming flatter, there still are significant barriers in the form of national borders. Chapter 2 discussed ideas and strategies to understand the differences in business environments because of these barriers. According to the CAGE distance framework, the differences in business environments due to national borders are wide-ranging and consist of cultural, administrative, geographical, and economic factors. These differences may be observed in the languages, religions, economic systems, and living standards present in each country. This chapter discusses a more fundamental principle of "institutional theory" in the context of differing business environments between nations, and examines its relationship to global strategy.

The 1993 Nobel laureate in economics, Douglas North, developed a theory that countries not only have codified "formal" institutions such as laws, but also have just as important and implicitly presented "informal" institutions such as the code of conduct and practices. North expounded on the relationship of these institutions to economic performance (North 1990). Among economic theories based on market transactions, such as product and labor markets, the field of "institutional economics" as developed by North, which studies the relationship between economic activities and informal constraints such as the code of conduct and practices, continues to be researched.

The behaviors of corporations and individuals within an economic society do not necessarily abide by the formal institutions, but they are often determined by informal restraints such as taboos and customs. This tendency is particularly apparent in developing nations such as China and India because these nations have been slow to enact various rules regarding economic transactions (corporate law, contract law for private transactions, property law including intellectual property, etc.). Even when laws have been codified, the enforcement of these rules has often been insufficient. 
For example, China has made three major revisions to its patent laws since their enactment in 1985, and intellectual property institutions are being strengthened because of calls for "indigenous innovation." However, the state of intellectual property protection in China is far removed from the country's tough patent system. China also implemented antimonopoly laws in 2008. However, its enforcement makes it appear like the objective is to protect domestic industry and limit foreign corporations.

It would appear that these countries are conforming to global standards by integrating modern legal structures from foreign countries and codifying them into rules; however, because the inertia of informal rules of economic transaction practices and societal behaviors is so strong, the enforcement of rules are quite literally all over the map. With the help of the WTO and regional economic partnership agreements, an international alignment according to formal economic rules is shaping. However, informal rules such as country-specific societal norms and customs do not change easily, and some doubt the hypothesis of converging into one global system. A concept often used within institutional economics is that of "path dependency." The thinking goes that because practices and rules for economic transactions are formed during a country's process of achieving economic development-a process that is determined by differing historical backgrounds and economic developments depending on a country - there exists several equilibriums. For example, some countries drive cars on the right side of the road, whereas others drive on the left. There are various theories as to why this difference exists; one of them is that the position of doors in horse-drawn carriages differed in England and France, but whatever the case, there is some historical background for this phenomenon. However, once a practice like this is set, it is extremely expensive to change and things remain in a state with several equilibriums. Incidentally, there is a field of study called "comparative (or historical) institutional analysis" that uses game theory to model path dependency and a state of multiple equilibriums to explain differences in institutions among countries (Aoki 2010; Grief 2006).

Institutions in various countries, including informal institutions, can be characterized as game rules for conducting economic activities. An examination of global business strategy cannot be engaged in without an understanding of these game rules. In Chap. 2, we discussed the state of global strategy considering primarily codified formal institutions. In this chapter, we progress one step further and consider the impact of institutions in economic society, including unwritten rules, on global strategy. Chapter 1 featured a company in an industrial park in Shanghai's Jiading district that was suddenly ordered by the government administration to exit the park. Codified rules granted contractual authority to companies within this industrial park to use the property for a specific length of time. However, the decision by the government administration can overturn this contract. These rules are not explicitly codified, but they nonetheless exist. Property rights in many regions of India are vague, and when discussions with local farmers in Tata Motor's appropriation of land in West Bengal did not go well, Tata made the decision to pull out of its planned factory construction. 
Once events like these occur, they become difficult to solve. Thus, it is important to increase our understanding of institutions, including their informal rules in countries, where a corporation is expanding, to understand possible strategies to avoid risk, or at least to keep losses from risks to a minimum. In this chapter, we compare and contrast China and India as we consider the relationship between economic societal institutions and global business. First, we examine foreign investment policy differences between the two countries. We then explicate institutional differences that arise because of the differences in each country's political and economic systems. Further, we examine views on global strategy on the basis of the institutional differences in India and China. In doing so, we also explain risk management as it applies to global business.

\subsection{Comparative Institutional Analysis of China and India}

\subsubsection{Overview}

The People's Republic of China was established in 1949 as a communist country under the leadership of Mao Tse-tung. Under the patronage of the then Soviet Union, a socialist state was created, but the Cultural Revolution, which lasted from 1966 to 1976, caused great turmoil. With the death of Mao Tse-tung in 1976, Deng Xiaoping took over the country's leadership, and in 1978, began implementing a policy of reform and opening up the nation that started the nation's economic development. Deng Xiaoping's economic policies enabled economic development by attracting foreign corporations, and in the 1990s, China implemented full-scale policies to further open the country's economy. As a result, direct foreign investment in China skyrocketed, and the number of Japanese companies investing in China grew rapidly. Currently, China is known as the "factory of the world," and consumers throughout the world cannot live without Chinese-made products. Since the 1990s, China's economic growth has consistently been at a high level of around $10 \%$, and as we have seen in Chap. 1, the country's economy has surpassed Japan, making China an economic giant second only to the US.

On the other hand, the Republic of India gained independence from the British Empire in 1947, at which time it was established as a social democracy headed by Jawaharlal Nehru, who served as the country's first prime minister. Each state in India has an independent economic system, and taxes and regulations are extraordinarily complex. In 1980, the regulations were relaxed to allow partial participation of foreign capital, but the impact of that relaxation was very limited compared with China. Because of the lack of basic infrastructure such as roads and electricity, India has many handicaps as a manufacturing base. Yet, recently, the rapid growth of the IT service industry, primarily in software development and business process outsourcing (BPO), has greatly changed India's image internationally. While China is the "factory of the world," India is the "world's software developer." The size of the Indian economy in terms of GDP is 


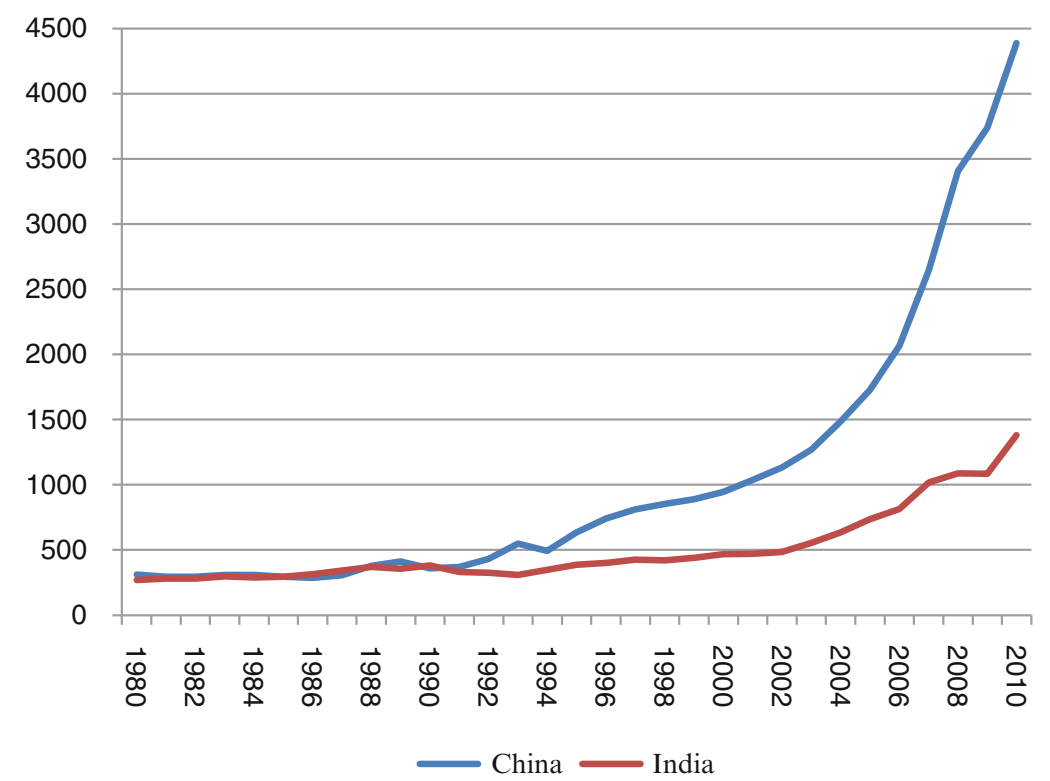

Fig. 4.1 Per capita GDP of China and India (Source: United Nations Statistics Division data)

still small, at about one-third the size of Japan's, but recent growth has been remarkable, and the country is predicted to be a giant market in the future.

Figure 4.1 shows the per capita GDP trends for China and India. The per capita GDP was about the same for both countries until 1990, but after that time, China's growth began to outstrip that of India. As of 2010, the per capita GDP was USD \$4,400 for China versus India's USD\$1,300, showing a huge gap. The source of this gap is thought to be the difference in policies for attracting foreign capital.

As shown in Fig. 4.2, direct foreign investment in China has been on an increasing trend since the 1990s. In contrast, for the most part, India had no visible direct foreign investment until about 2005, and only began to grow from 2006. Foreign investment growth in both countries declined in 2009 because of the financial crisis brought on by the Lehman Brothers' bankruptcy, but the cumulative total investment to date is still overwhelmingly large in China. Deng Xiaoping, who directed policies to open up China to the outside world, visited Wuhan, Shenzhen, Zhuhai, Shanghai, and other southern Chinese cities in 1992, personally witnessing the economic development of this economic zone made possible through the allowance of foreign investment, and confirmed the effect of an economic development model relying on attracting foreign capital. As a result, in his "southern tour speech," Deng declared his intent to expand the reform that attracted foreign capital-which up to that point was restricted to certain regions - all over China. As a result, investments in China by foreign firms began in earnest.

Another turning point for direct investment in China came with their WTO membership in 2001. Until the 1990s, foreign investment in China was made at the 


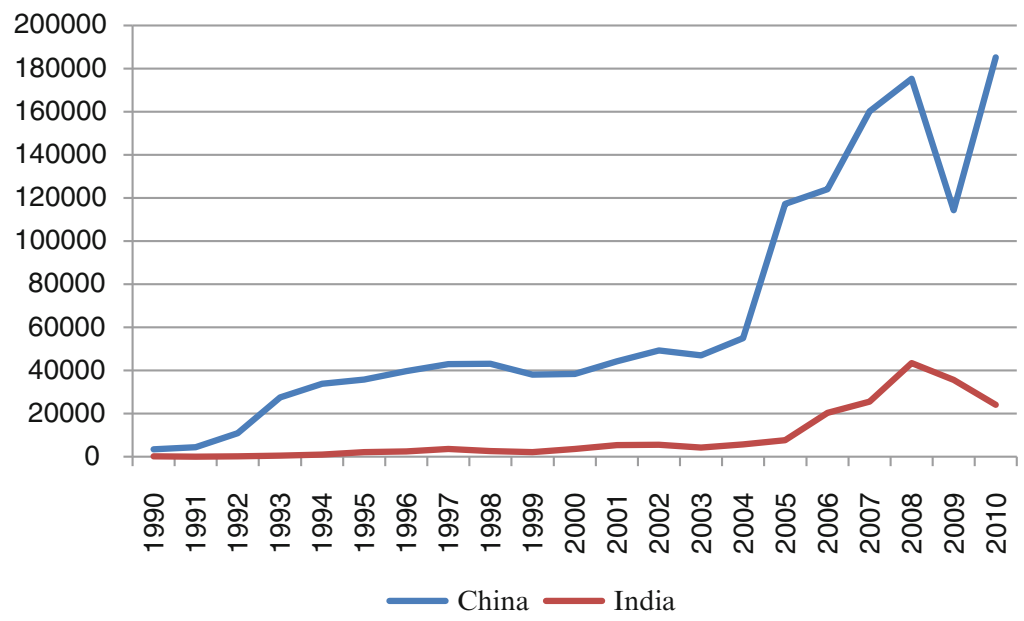

Fig. 4.2 Inward foreign direct investment of China and India (billions of dollars) (Source: ADB Key Indicators for Asia and the Pacific 2011 (August 2011))

request of the Chinese government authorities. However, China's WTO membership sent a message that the Chinese government would create an environment for investment that accorded with international rules, thereby reducing investment risks for foreign firms. In addition, the WTO membership paved way for deregulation such as the gradual elimination of foreign capital regulations in service industries like finance and distribution, which had a tremendous impact on direct investment.

The Indian economic policy, on the other hand, still has marked remnants of protectionism for domestic industries, and investment risk is still a significant issue for foreign firms. When India gained its independence in 1947, Prime Minister Nehru implemented the concept of planned economy from the then Soviet Union, controlling the domestic economic activities through various regulations. These regulations were not only for foreign transactions but also for domestic operations, and the phrase "License Raj" ("Raj" is a term that means "rule" or "reign," and was used during the period of British colonial rule) became a cynical phrase implying that Indian people were ruled by licenses rather than the British. The situation has significantly improved since then, but there are still many significant barriers to investment, such as labor laws to protect workers, business registrations, and a complex tax code. In addition, manufacturers are impacted by the lack of infrastructure such as roads and railways. On the flipside, IT services and software, which are not as affected by the lack of physical infrastructure, have seen a tremendous amount of investment, primarily from European and US firms. That said, India created special economic zones in 2005, developed industrial parks, and worked to lure foreign capital to its manufacturing industries. In addition, the government began relaxing foreign investment regulations since the early 2000s, resulting in direct domestic investment growing rapidly since 2006 (Table 4.1). 
Table 4.1 Major politics and economics events in China and India

\begin{tabular}{|c|c|c|}
\hline India & Year & China \\
\hline Bombay (Mumbai) Stock Exchange & 1875 & \\
\hline \multirow[t]{7}{*}{ Independence from British } & 1947 & \\
\hline & 1949 & Country was formed \\
\hline & 1959 & 15 million deaths due to starvation \\
\hline & 1966 & Start of Cultural Revolution \\
\hline & 1976 & End of Cultural Revolution \\
\hline & 1978 & $\begin{array}{l}\text { Liberalization of economy, aggressive } \\
\text { implementation of direct domestic } \\
\text { investment }\end{array}$ \\
\hline & 1979 & Start of "One Child" policy \\
\hline \multirow[t]{5}{*}{$\begin{array}{l}\text { Deregulation policies focused on automotive } \\
\text { industry }\end{array}$} & 1980 & $\begin{array}{l}\text { Decision to create economic zones in } \\
\text { Shenzhen, Zhuhai, Shangtou, and } \\
\text { Xiamen }\end{array}$ \\
\hline & & First financial reform \\
\hline & & $\begin{array}{l}\text { Start of the "Contract Responsibility } \\
\text { System" }\end{array}$ \\
\hline & 1981 & \\
\hline & 1982 & $\begin{array}{l}\text { Start of agriculture reforms; } \\
\text { implementation of "Farmer } \\
\text { Management Responsibility System" }\end{array}$ \\
\hline \multirow{5}{*}{$\begin{array}{l}\text { Deregulation of consumer electronics and } \\
\text { software sectors }\end{array}$} & 1984 & \\
\hline & 1985 & $\begin{array}{l}\text { Coastal cities opened to foreign } \\
\text { investment; creation of economic } \\
\text { technology development zones }\end{array}$ \\
\hline & 1986 & $\begin{array}{l}\text { Implementation of Management } \\
\text { Responsibility System to split } \\
\text { ownership and management of } \\
\text { state-owned enterprises }\end{array}$ \\
\hline & 1989 & Tiananmen Square incident \\
\hline & 1990 & Shanghai Stock Exchange open \\
\hline $\begin{array}{l}\text { Economic rebuilding and deregulation of } \\
\text { foreign investment }\end{array}$ & \multirow[t]{3}{*}{1991} & \\
\hline $\begin{array}{l}\text { Gradual elimination of import licenses and } \\
\text { lowering of tariff rates }\end{array}$ & & \\
\hline Deregulation of foreign investment inflow & & \\
\hline Liberalization of foreign exchange & \multirow[t]{4}{*}{1992} & \multirow{2}{*}{$\begin{array}{l}\text { Deng Xiaoping's Southern Tour } \\
\text { Speech; support for economic reforms } \\
\text { and policies for accelerated economic } \\
\text { growth }\end{array}$} \\
\hline Reform of commerce bank system & & \\
\hline Deregulation of interest rate system & & \multirow{2}{*}{$\begin{array}{l}\text { Decision on path toward "socialist } \\
\text { market economy" }\end{array}$} \\
\hline National Stock Exchange established & & \\
\hline $\begin{array}{l}\text { Authorization for foreign investors to trade } \\
\text { shares of publicly traded Indian companies }\end{array}$ & \multirow[t]{2}{*}{1993} & \multirow[t]{2}{*}{$\begin{array}{l}\text { Start of state-owned enterprise } \\
\text { privatization }\end{array}$} \\
\hline Removal of dual exchange rates & & \\
\hline
\end{tabular}


Table 4.1 (continued)

\begin{tabular}{|c|c|c|}
\hline India & Year & China \\
\hline \multirow[t]{3}{*}{ National Stock Exchange (NSE) open } & \multirow[t]{3}{*}{1994} & Second financial reform \\
\hline & & $\begin{array}{l}\text { Implementation of foreign exchange } \\
\text { system reforms (official RMB } \\
\text { exchange rate devalued by } 50 \% \text {, } \\
\text { move to floating exchange rate } \\
\text { system) }\end{array}$ \\
\hline & & International trade surplus \\
\hline WTO Membership & 1995 & $\begin{array}{l}\text { Implementation of Commerce Bank } \\
\text { Law }\end{array}$ \\
\hline \multirow[t]{4}{*}{$\begin{array}{l}\text { Complete liberalization of interest rates and } \\
\text { disposal of bad bank debt }\end{array}$} & \multirow[t]{4}{*}{1997} & $\begin{array}{l}\text { Foreign banks to trade RMB } \\
\text { (restricted to Shanghai's Pudong } \\
\text { region) }\end{array}$ \\
\hline & & July: Return of Hong Kong \\
\hline & & $\begin{array}{l}\text { September: Full implementation of } \\
\text { stock system for state-owned } \\
\text { corporations }\end{array}$ \\
\hline & & $\begin{array}{l}\text { October: Tariff reductions from } 23 \\
\text { to } 17 \% \text { on more than } 4,800 \text { products }\end{array}$ \\
\hline \multirow[t]{3}{*}{$\begin{array}{l}\text { Liberalization of foreign stock investment } \\
\text { regulations }\end{array}$} & \multirow[t]{3}{*}{1999} & $\begin{array}{l}\text { March: Acceptance of privately } \\
\text { owned companies }\end{array}$ \\
\hline & & $\begin{array}{l}\text { November: Decision to develop } \\
\text { western China }\end{array}$ \\
\hline & & December: Return of Macao \\
\hline $\begin{array}{l}\text { Aggressive implementation of direct domestic } \\
\text { investment }\end{array}$ & \multirow[t]{2}{*}{2000} & \\
\hline \multirow[t]{4}{*}{$\begin{array}{l}\text { Acceptance of foreign majority ownerships } \\
\text { outside of banking insurance, } \\
\text { telecommunications, and private aviation. } \\
\text { Most industries allowed } 100 \% \text { foreign } \\
\text { ownership }\end{array}$} & & \\
\hline & \multirow[t]{2}{*}{2001} & $\begin{array}{l}\text { March: Beijing wins } 2008 \text { Olympics } \\
\text { bid }\end{array}$ \\
\hline & & December: WTO membership \\
\hline & 2003 & $\begin{array}{l}\text { Authorization for foreign investors } \\
\text { to trade shares of publicly traded } \\
\text { Chinese companies }\end{array}$ \\
\hline Creation of economic zones & \multirow[t]{4}{*}{2005} & \\
\hline $\begin{array}{l}100 \% \text { foreign investment in real estate } \\
\text { development allowed }\end{array}$ & & \\
\hline $\begin{array}{l}\text { Maximum percentage of foreign investment } \\
\text { in financial and telecommunications industry } \\
\text { firms raised to } 74 \%\end{array}$ & & \\
\hline \multirow[t]{2}{*}{$\begin{array}{l}\text { Foreign investment approval process greatly } \\
\text { simplified }\end{array}$} & & \\
\hline & 2006 & $\begin{array}{l}\text { Start of foreign stock investment } \\
\text { liberalization }\end{array}$ \\
\hline
\end{tabular}


Japanese corporate investments into China and India are at USD $\$ 66.5$ billion and USD \$13.6 billion, respectively (till end of 2010), and investment in India is approaching to roughly one-fifth of Japan's investment in China. However, a closer examination reveals that Chinese investments cover a breadth of industries ranging from manufacturing industries such as automotive and electronics to retail and financial services. Indian investment, on the other hand, is primarily in the automotive industry.

\subsubsection{China: State-Led Strategic Foreign Investment Policies}

Deng's policies, which began in 1978, opened the country to trade and lifted the ban on direct investment from foreign countries. The following year the Joint Management Law (the Sino-Foreign Mutual Corporate Investment Law) was passed, creating institutional foundations for enticing foreign firms through the introduction of foreign capital, transfer of technology, and promotion of exports. In addition, in 1980, the Chinese government established four economic zonesShenzhen, Zhuhai, Shantou, and Xiamen-to experiment with economic development models to attract foreign firms. The government developed infrastructure to lure foreign firms to these zones and implemented preferential policies such as tax breaks for these firms. In 1984, the country opened 14 coastal cities to foreign investment, including Shanghai, Tianjin, and Dalian, and in 1986, regional restrictions on independent investments by foreign firms were lifted through the passage of the Foreign Enterprise Law. In 1988, almost all coastal regions became a part of the coastal economic liberalization zone through the government's implementation of a coastal zone economic development strategy.

Market reforms accelerated as a result of Deng's 1992 southern tour speech, and the investment of foreign capital into the country began in earnest. Between 1995 and 1997, the Chinese government began opening up domestic markets with the goal of acquiring WTO membership, and also started liberalizing trade by implementing measures such as reducing tariffs. In the latter half of the 1990s, China attracted foreign capital with abundant preferential policies and cheap labor as weapons, thereby establishing itself as the "factory of the world." A plan to develop western China kicked off in 1999, and the opening up of China to foreign markets moved from coastal regions to the country's interior. In 2001, China became a member of the WTO, and with further loosening of foreign capital restrictions in the service industries, China saw a dramatic rise in the amount of direct investment.

The methods of capitalization in China include independent foreign capitalization (wholly owned firms) and joint capitalization in the form of a joint venture with a Chinese firm. Until the 1990s, direct investment in China was often done at the request of local governments, and many of those investments were made as joint ventures with local firms. However, with China joining the WTO in 2001, the country gradually eliminated restrictions on foreign capital. This relaxation applied not only to the manufacturing industry but also to service industries such as distribution and finance, with many industries freely able to decide whether to create a wholly 
owned subsidiary or joint venture. However, it is important to note that industries such as the automotive industry, which are viewed as strategically critical by the Chinese government, have their own rules. For example, in the automotive industry, foreign firms are not allowed to establish a wholly owned subsidiary, and are restricted to less than $50 \%$ ownership in joint ventures.

In the 11th 5-year plan that began in 2006, the Chinese government clarified its stance on the selection of investments by foreign firms and outlined its goal for becoming a "technology nation" with heightened competitiveness of Chinese firms. In January 2008, the government enacted a labor contract law that improved worker compensation, as well as a new corporate income tax law that eliminated preferential income tax breaks on foreign firms. Currently, the Chinese government hopes to bring in high-tech companies and environmental firms that will contribute to the development of the country, rather than simple manufacturers and assemblers that have, to date, dominated China's landscape. Given the reductions in preferential policies for foreign capital, the rise in labor costs, and a stronger Chinese currency, foreign firms are beginning to change their investment strategies in China. Some foreign firms are examining a setup of bases in nearby countries such as Vietnam to distribute their risk, in what is known as a "China Plus One" strategy.

\subsubsection{India:The Steady Progress of a Democratic State}

Deregulation in India began in 1980 when Indira Gandhi became the prime minister. The automotive and electronics sectors were pioneers in this deregulation. Suzuki used it as a chance to acquire a leg-up in the market, creating the Maruti Suzuki joint venture with the state-owned Maruti Udyog Limited. However, at the start of the 1980s, economic liberalization policies had not been fully put in place and, other than Suzuki in 1982, no other expansion into India's passenger vehicle market by foreign firms was allowed. While Toyota, Mazda, Mitsubishi, and Nissan formed joint ventures and technological alliances in the commercial vehicle market in India, their results were poor and they were forced to exit the market.

In addition, deregulation in the 1980s was done in an extremely closed market, with extraordinarily strict regulations on trade. The tariffs were high and limits were placed on import volumes. All imports of consumer goods were forbidden; imports of capital goods, raw materials, and work-in-process goods were sometimes allowed, but import licenses were required for any goods that could be manufactured domestically.

In the latter half of the 1980s, India fell into budget deficits and received assistance from the IMF and World Bank. From early 1990s, India worked to rebuild the country by implementing new economic policies. The country first improved its trade system, aiming to liberalize trade by gradually abolishing import licenses and reducing tariffs. Further, authorization for direct foreign investment, while varying by industry, was granted automatically to a certain extent, and the time it took to obtain authorization shortened. It was in this period that DaimlerChrysler, GM, and Ford as well as Japanese automakers' direct investment in India grew rapidly. At the 
same time, investors from foreign institutions were allowed to trade shares of public companies.

However, the Indian government did not begin its full-scale analysis to entice foreign capital until after the year 2000. India had a strong aversion to foreign capital because of its days under the British colonial rule, and the deregulation of foreign investment was only gradually accomplished. A major turning point in India on foreign capital regulation occurred in 2002 when the Indian government's Department of Commerce changed the theretofore one-off approval system for direct investment into a "negative" system. In doing so, industries not on a government list were automatically granted investment approval. In addition, industries such as electric transmission, financial services, and real estate were deregulated in 2005. The aggressive investment by foreign firms that occurred beginning in 2005 was because of policy measures that were put in place in India at that time.

Further, India enacted an Economic Zone Law in 2005, and as a result, hundreds of plans for construction are said to currently exist throughout the country. These economic zones have the aim of spurring exports and consist of many wholly owned subsidiaries of foreign concerns across a range of industries. The companies in the economic zones enjoy preferential treatment under the tax system. However, despite having received permission to do so, only a portion of the zones have undertaken construction, with many unable to establish construction plans because of local resistance.

\subsubsection{Comparison of Political Systems}

Both China and India began as countries during the latter half of the 1940s, and both countries modeled their economic policies on the planned economy of the Soviet Union that existed at the time. For different historical reasons, both countries had completely closed their doors to the outside world at the time of their independence: China due to international political tensions between east and west, and India due to its past as a British colony. While they started at similar places economically, the two countries' political systems were completely different. China is, in reality, under one party rule of the Communist Party. On the other hand, India chose the path of democracy and elects its central and local government leaders by popular vote. This difference in political structures leads to very different investment environments from the perspective of foreign firms.

In comparing both countries, Tarun Khanna poses an interesting question, "Why can China build cities overnight, yet India can't build a single road?" (Khanna 2007). This question captures the essence of institutional differences between China and India. Under the leadership of Deng Xiaoping in the 1990s, China aggressively pursued policies to open itself to foreigners. This was carefully done by first examining the results of experimental policies in certain regions, and then determining it to be the path to take for the entire nation. In addition, India dramatically reformed its trade system in the 1990s, gradually opening its doors to the outside world. However, this was done as a decision to rebuild after running budget deficits, a 
decision that was forced upon them because of the fear of impending bankruptcy. In democratic India, the leaders of the nation cannot establish policies that went against the people's will. One can easily imagine that because of its history as a British colony, the national sentiment was to oppose opening the country to foreigners. In these circumstances, a strong motive such as a national crisis was necessary to promote the path to reform.

Let us examine the political systems of China and India in greater detail. The legislative body in China is called the National People's Congress, comprised of members from provinces, autonomous prefectures, and directly controlled municipalities who are elected by their respective People's Congresses. People's Congresses are organized for each local government organization below provinces-the cities and prefectures - and citizens may only participate in elections at the prefecture level and lower. However, many delegates are essentially recommended by local organizations of the Chinese Communist Party and are "elected" by the people through a vote of confidence. These delegates themselves elect the National People's Congress members; therefore, it is unlikely that members who are critical of the Communist Party will ever be elected. The National People's Congress not only fulfills its responsibility as a lawmaking organ but also acts as a supreme authority, even in areas of administration, judiciary, and prosecution. The National People's Congress is made up of roughly 3,000 members from across China, even though important policy decisions for the country are essentially made by the Communist Party's Central Committee, which had nine members as of September 2012. While these nine are ranked, decisions are made by a majority vote. The top ranking member is the head of state. Personnel decisions such as the heads of local administrative organizations in provinces and directly controlled municipalities are also essentially appointed by the Communist Party, making China a state run by one organization: the Communist Party.

On the other hand, India is a democracy much like Japan. India has many political parties, with candidates from each party competing for seats in the national parliament (bicameral parliament, consisting of upper and lower houses). It is difficult for one party to gain a majority, so coalitions are the norm, with a prime minister selected from among the representatives. In the 2009 general election of the Lok Sabha, or lower house, the United Progressive Alliance (UPA), India's largest party and a coalition led by the Indian National Congress, became the ruling party. The minority coalition is the National Democratic Alliance, with the Bharatiya Janata Party, or BJP, at its core. In general, the Indian National Congress takes up liberal policies of economic reform, while the BJP favors conservative policies for domestic protectionism. However, as a farming nation, the opinions of the country's farmers are important during election time, and domestic policies are always given priority over issues of foreign concern. With so many political parties, administering a government is also difficult. Another factor making political decision-making in India difficult is that state governments, which also hold direct elections, wield strong influence in the administration of policy.

These differences in political structure are well expressed in Khanna's observation that "China can build cities overnight, but India cannot build even a single 
road." Likewise, these differences are prevalent in the development of foreign investment policies implemented since the 1990s. China implemented coherent policies with the aim of economic development through enticement of foreign firms. However, in India, things have not progressed as smoothly. Although India finally implemented policies favorable to foreign investment in earnest beginning in the 2000 s, economic zone constructions have not moved forward as expected. This is because of the political power of landowner famers and the time taken to appropriate land. As the line "India cannot build even a single road" suggests, improvements on roads and railway infrastructures, in addition to the industrial parks, are not progressing as planned, instead becoming a barrier to attracting foreign investment.

\subsubsection{Comparison of Economic Systems}

From the perspective of political structure, China is proceeding more smoothly in implementing policies for foreign investment and economic development. However, from the perspective of economic systems, particularly corporate activities and market mechanisms, India is superior. In his book, Tarun Khanna asked the question, "Why can large companies be created in China, with only a handful of them being competitive internationally?" India has companies such as Infosys that is hailed in the book "The World Is Flat," and Tata Motors, a well-known manufacturer of passenger vehicles. In addition, Mittal, India's steel manufacturer, merged with Europe's Arcelor to become the world's largest steel company.

China's Communist Party created an economic system in which, pursuant to the construction of a socialist state, the state owns all assets and distributes these assets to the citizenry. Formerly, China had privately owned companies similar to the Tata Group, but they escaped to Taiwan, Hong Kong, and other locales when the People's Republic of China was established. With the economic reforms of Deng Xiaoping starting in 1978, the country began integrating competition via market mechanisms into the domestic planned economy. The country did away with the system of wealth distribution through state-owned corporations that followed planned production activities, as well as price controls, implementing a system of free trade of goods in product markets. The reforms for state-owned corporations were put in place and many companies moved to become joint stock entities with limited shareholders or limited liability corporations. Figure 4.3 lists the changes in share of total value added by form of ownership among Chinese manufacturers $(20,000-40,000$ medium- and large-sized firms). The state-owned corporations commanded over $70 \%$ share in 1995, but decreased to roughly $20 \%$ in 2011. On the other hand, limited liability corporations (or joint stock companies) had the greatest share increase. The greatest change occurred in the period from the latter half of the 1990s to the first half of the 2000s because of the reforms for state-owned companies that were put in place from 1998 to 2000 by then prime minister, Zhu Rongji. The aim of those reforms was to "grab the large and free the small," i.e., the state would directly control large firms, whereas small firms would be converted to joint stock entities and its corporate activities liberalized. The State-Owned Assets Supervision 


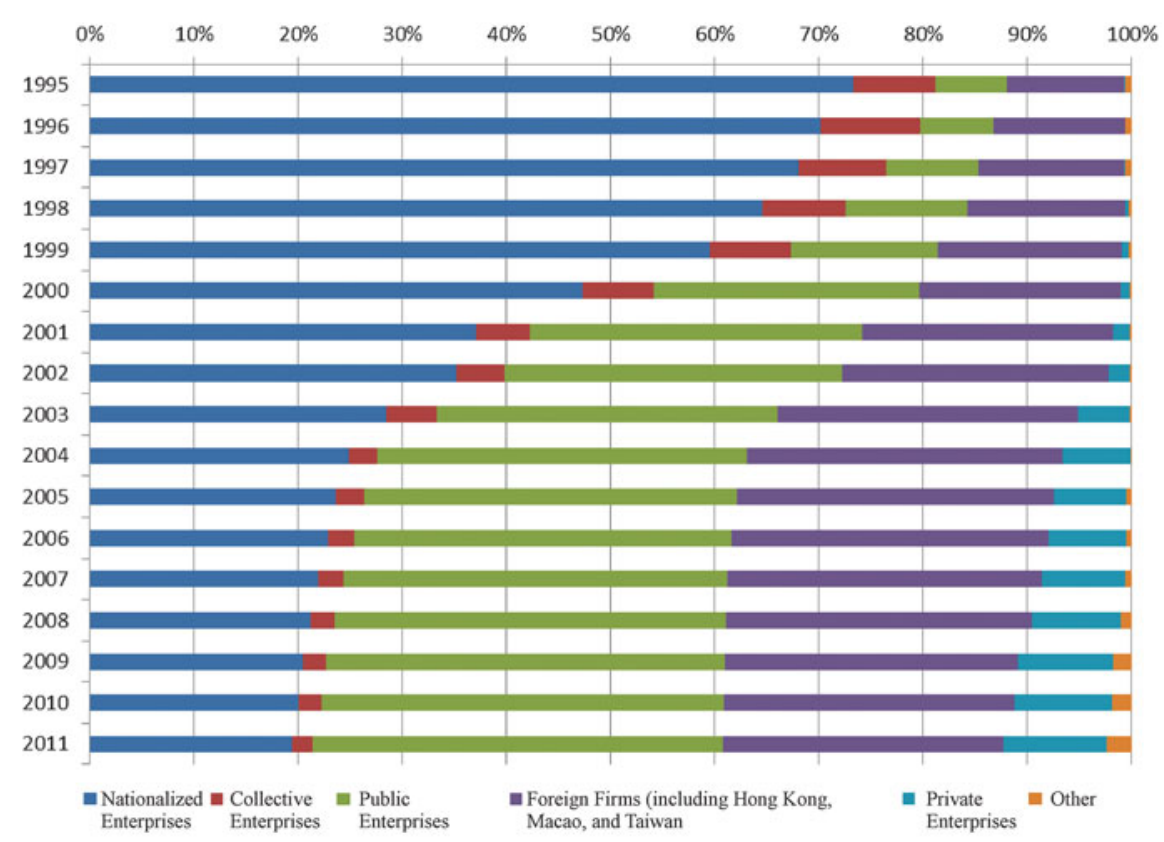

Fig. 4.3 Share of value added by type of ownership among Chinese manufacturers (Source: Estimates compiled from China National Bureau of Statistics data)

and Administration Commission (SASAC) was created in 2003 to keep management of all state-owned enterprises in one place. However, companies that had been converted to joint stock firms often had the government or government personnel as major shareholders, so a large portion of the Chinese economy was still essentially under the control of national or local governments.

Until it was revised to allow for individual ownership of assets in 1999, making possible the creation of fully private firms, private companies were forbidden under the Chinese Constitution. It was possible to manage private businesses as entities called "individual companies," but revisions to laws allowed for purely private management of firms as companies. However, while the number of private companies in China is large, most are small businesses because everything in the business world in China happens with government involvement. For example, when funding from financial institutions becomes necessary for a new venture, banks will prioritize funding to private corporations backed by the government for its perceived low risk. Under competitive circumstances, there should be banks that will take risks and invest in powerful private firms. However, most large banks are state-owned, with once again bringing the overall industry under the strict control of the state. Huawei Technologies is one of the few private Chinese companies that is internationally competitive. Founded in 1988 as a wholesaler of telecommunications equipment manufactured overseas, Huawei has become a truly global vendor with half of its 
revenues from switches, cell phones, and other telecom equipment sold outside China. However, even Huawei had difficulty raising capital when it was starting out.

The importance of government relations is not limited to raising capital. As observed in Fig. 4.3, state-related businesses account for a great share of the Chinese economy. Accordingly, the counterparties to the private companies that operate in China are state-related businesses. In a B2C business model, sales channels are necessary to deliver a company's products to consumers. Because deregulation in the distribution market, whether wholesale or retail, has been delayed, companies are forced to do business with companies having some connection with the government. Thus, the bureaucracy in China-and in its background, the Communist Party - has spread its net wide across economic activities, making it impossible to do business without touching its network.

However, India has an economy primarily driven by private companies. The core companies among these are multifaceted group companies such as the Tata, Reliance, and Birla Group. For example, the Tata Group began as a textile mill in Bombay (today's Mumbai) in 1870, and continued to grow its operations after Indian independence. Among its group companies are Tata Motors, the third largest passenger vehicle maker in India, and Tata Consultancy Service (TCS), India's largest IT services firm. Other group companies span a broad array of industries including power, steel, and wireless services. There are companies like Infosys, which started in 1981 with the equivalent of 30,000 yen in capital, and has grown to become one of the few world-class IT service company today that threatens the dominance of IBM. Unlike China, the Indian government was historically seen as something that got in the way of private business. Since the economic reforms of 1991, government organizations are said to have become more supportive of business activities (Capelli et al. 2011), although the situation is completely different from China, where government organizations are the primary drivers of business.

The greatest structural difference in Chinese and Indian companies is that those in China are built through their various relationships with government, whereas those in India are private companies that compete in the midst of market mechanisms. Of course, the maturity of product and financial markets in India is nowhere near that of developed countries. The remnants from the era under the "License Raj" regulatory scheme, when activities were heavily bound, still exist in the complex systems for establishing and ending companies, taxes, and labor. In wholesale or other distribution industries, India has stricter regulations than even China and its infrastructure lags. Many government regulations mean that opportunities also increase for civil servants to exercise discretion at the local level, which is one reason briberies given to civil servants are rampant. However, the situation is quite different from China, where governmental decision-making at the national and local levels impacts every aspect of business.

The differences between these two countries are evident in the way risk is managed in running the national economy. In India, manufacturers, distributors, banks, and various other companies each assess risk and reward under the mechanism of a market economy, and then engage in business activities. Further, codified rules such as corporate and labor laws as well as financial market regulations are created with 
the intent to complement market mechanisms. The companies are able to engage in business, assuming that their counterparties and funding partners are going to act in accordance with the weighted risks and rewards. Trust in these market mechanisms exists as a code of conduct in Indian business.

In China, business owners do not take on all the risk themselves, rather the government shoulders a portion of that risk. In return, the state demands that the business act in alignment with bureaucratic objectives. The Communist Party manages the state, and advancement in the party hierarchy is said to be determined in provincial and municipal level "tournament games," where economic growths at one local government is pitted against another (Xu 2011). This system led to local governments battling over one another to attract foreign firms, and as a result, it enabled China to maintain high economic growth rate to date on the basis of liberal policies. The policies themselves are not decided at the central government level, which simply sets a certain direction and leaves the rest to the discretion of heads of local governments, so that they might compete more effectively. As such, it is imperative for companies to surmise the views of the local government when doing business in China.

Although China is implementing reforms such as state-owned enterprise reforms and the creation of corporate law to move toward a market-based economy utilizing market mechanisms, the behavior of economic entities in the country follows the informal rules of a socialist state. As a result, capital and financial markets continue to be immature, making it difficult for companies that are internationally competitive to be formed. The 11th 5-year plan that began in 2006 has the creation of "indigenous innovation" as its key objective, which aims for new inventions that are internationally competitive to be home-grown, rather than be produced by importing technologies from the West or Japan as was done in the past. Local governments must now implement specific policies based on this vague goal. However, innovation is only a possibility through constant competition and ingenuity of individual companies. Thus, it will be difficult to obtain this goal if corporate managements run their organizations while gauging the local government's mood and reaction as they have done so far. Therefore, there are few companies in China that can compete internationally, even though the country has large state-owned corporations.

\subsection{Global Strategy Implications}

\subsubsection{Institutional Voids}

The difficulty of managing a global business in emerging countries arises because the local institutions in their respective economic systems are very different from those of the developed nations. As discussed in the previous section, China and India have great differences in their institutions. We stated that Indian institutions are built on the foundation of market mechanisms, but that the effectiveness of these mechanisms in the country is not even close to that of developed nations. On the other hand, China's economic system is unique with the government's direct involvement in every aspect of economic activity; however, it has more efficient 
markets than those in India, such as the product and labor markets. The institutional differences by country strongly correlate to the level of efficiencies in diverse markets such as product, capital, and labor markets. We term nonfunctioning market mechanisms as "institutional voids," and introduce a methodology for analyzing global strategies on the basis of this term.

"Institutional voids" are economic institutions such as product, capital, or labor markets that have matured in developed nations, but have not reached a sufficient level of maturity in emerging markets, thus creating a void (Khanna and Palpu 2010). These researchers define the difference between emerging and developing countries by the degree of void. The emerging countries are countries like India and China that have immature economic institutions compared with developed nations, but have somewhat of an institutional foundation, thereby limiting the size of the void. On the other hand, developing countries are countries that do not have an institutional base, where the institutional void is so excessively large that companies accustomed to operating in developed nations with no institutional voids must use completely different business models to succeed there.

We use the above definition in our discussion of "emerging countries," but must provide clarity into certain institutional voids. We have created four classifications of voids:

1. Voids in product markets

2. Voids in capital markets

3. Voids in labor markets

4. Macroenvironments related to institutions

First, we discuss the voids in product markets, which are determined by the following two factors: the extent products and services can be purchased by consumers on the basis of correct information, and whether market thickness can be secured with sufficiently functioning competitive markets containing many buyers and sellers. Thus, the efficiency of sales channels of wholesalers and retailers as well as the state of logistics and infrastructures are related to this type of void. When comparing China and India on these points, China might be said to have relatively smaller voids (i.e., more efficient). The restrictions on foreign capital in the distribution industry have been significantly relaxed in China, resulting in companies such as Carrefour and Walmart entering the Chinese market. However, India still has strict regulations on that industry. China also has more advanced infrastructure, making logistics more efficient.

In the case of voids in capital markets, India has smaller voids, thus more efficient markets. As noted above with regard to bank lending, in China, government organizations exert heavy-handed control over lending by financial institutions. In stock markets, China's publicly traded corporations have only a portion of their shares available to the market and often more than half are owned by governmentrelated entities (i.e., nonpublic enterprises). As a result, the true state of a publicly traded company is unclear based on the available financial information, making information asymmetry between companies and investors a big concern. On the 
other hand, India has had bank financing and stock trading since its colonial era, and as such, issues like the ones observed in China are relatively small.

Third, we discuss the voids in labor markets. This type of void is determined by how efficiently labor demand (corporations) is matched with supply (i.e., workers). On this point, the void in China is relatively smaller. India has extremely strict labor regulations, and it is practically impossible for corporations of a certain size to sack employees. In addition, unions are very active and there are many selection biases when hiring employees. Differences in language depending on the region and lack of women entering the workforce also negatively affect labor market efficiency. China has relatively higher worker mobility, and while there are heightened sense of worker entitlement and stronger regulations protecting workers, these issues are small in comparison with India.

Finally, macro environments relating to institutions encompass many areas including foreign capital regulations, broadcasting regulations, and regulations on the activities of foreign firms. We briefly discuss Chinese media regulations. The content of newspapers, magazines, and other forms of media in the country are checked stringently. It is possible now for individuals to publish their own information on the Internet in the form of blogs or similar formats, but cyber-cops keep a close watch on Internet discussions, and objectionable opinions are censored on a daily basis. However, these information regulations apply to politically sensitive content, so economic information such as corporate financials and product information is not impacted as much, making the impact of this factor on China's institutional voids minimal.

Having listed these voids, the global strategy based on Khanna's “institutional voids" is to select one of the following, depending on the circumstances: (1) replicating domestic business or (2) adapting to the local environment. This is similar to the discussion of "aggregate" and "adapt" in the AAA framework discussed in Chap. 2. The former should be selected to achieve economies of scale or to leverage a global brand; the latter should be selected when voids are too large and a strategy of replication is unrealistic.

In addition, we have discussed the model of using voids as business opportunities (the model that could be called "arbitration" in the AAA framework). As an example of this, the German retail firm Metro Group has a cash-wholesale business in India called "Metro Cash and Carry," which provides a wealth of clues as to how to accomplish the goal of this model. Metro Group's business exploits India's institutional void of an inefficient distribution system. The business was started as a cash and carry service in Bangalore in 2003, and has since expanded throughout India. However, India has regulations on the trade of agricultural products (trade on these products within India must be conducted in government-authorized markets called "mandis"), making it impossible for Metro Group to deal in agricultural products. This law was created during the 1950 s to protect farmers, but is currently an impediment to improving agricultural distribution. Agricultural products in India must be fresh, but a large amount of product goes waste during distribution, and even the government acknowledges the need to revise the law. At present, movements are afoot in some states to do so, but they have met with opposition in multiple states, 
especially from masses of individual businessmen who buy and sell under the system of mandis. Metro Group is working hard in appealing to both farmers and consumers that eliminating the law will be beneficial for both. When institutional voids become business opportunities, local systems are established in response to such voids; however, these local systems can also become large barriers. Businesses must assess the viability of conducting business by understanding these types of risks, and must be prepared to make long-term investments for the success of that business.

In addition, businesses have strategically important options of whether to tackle institutional voids alone or jointly with a local business. As deduced from the Metro Group example, businesses do not necessarily need to embrace voids; rather, it can be effective to work with local firms in making a long-term investment to reduce local voids. Other companies have entered the cash and carry business in India, for example, Tesco in the UK announced its intentions of partnering with the Tata Group to join the market. From the perspective of foreign firms, China and India are full of institutional defects, but companies are doing business within the confines of these local institutions. If a company recognizes a defect it believes will be difficult to overcome independently, there is value in considering a partnership with a local firm before conceding defeat entirely.

\subsubsection{Importance of Informal Institutions}

Compared with advanced nations in which market mechanisms function effectively, "institutional voids" concept begins by clarifying the institutional problems that beset emerging nations. Accordingly, the institutional market is an important topic studied within institutional economics, though these studies only incorporate a portion of the framework and does not incorporate informal institutions such as social codes of conduct and practices. Reflecting back on our comparison of the overall economic institutions including informal institutions in China and India, let us now consider their implications in terms of global strategy.

First, we must emphasize the necessity of strengthening our understanding of institutions, including informal rules such as codes of conduct and practices in corporate economic activities, in addition to explicit rules such as economic laws that are part of economic institutions in target countries. In particular, informal rules are structured over time in the process of economic development, and reflect the historical background and political systems of that country. Thus, they are a critical factor underlying economic activities. In this regard, the desire of the government is clearly reflected in various aspects of corporate economic transactions in China. In contrast, market competition among private companies drives the rules of the game in India. However, in our discussion of "institutional voids," India is fragmented by complex regulatory systems and markets from the aspect of market mechanism efficiency, and it indicated how far away these are from the level of advanced nations. In both China and India, reforms are underway for the creation of corporate law and regulatory systems, and both countries are working on economic systems based on 
global standards in accordance with the WTO rules. However, even if codified laws and guidelines change, actual economic activity will not change very easily because of entrenched informal codes of conduct. Thus, the likelihood of failure will increase if a company bases its business decisions only on codified rules.

Next, the relationship with the government is particularly important for businesses in emerging markets. China has a unique economy in which political processes that determine national leadership take place in the Communist Party, and economic development objectives are achieved through a system of "elimination tournaments" at the local government level. However, a common fact among emerging markets is that local government policies and decision-making have a significant impact on global business. India has many institutional voids, but industrial policies such as government regulations and regional revitalization rules are making actual economic activities possible by filling market mechanism voids. In emerging nations with slow development of the private sector, government is often the partner of businesses. For example, in the next chapter, we examine infrastructure businesses such as railways and water; in these businesses, even though the end consumer is the general public, the government acts as an intermediary as a B2G2C business. As such, it is important to maintain good relationships with government organizations and build business models that can accomplish a win-win relationship. In addition to revitalizing regional economies, local governments enforce policies with various goals such as providing stable living environments for citizens and improving the environment. It is important to consider business strategies that not only generate profitability but also contribute to these government objectives, or in other words, contribute to the value proposition for the government. Finally, let us discuss risk management as it relates to global strategy for emerging nations posing high levels of uncertainty. Investment decisions for a global business must consider various risks such as local macroeconomic environments, exchange rates, and other economic risks; labor relations, procured parts quality, and other operational risks; and societal risks such as opposition to foreign firms. It is possible to deal with economic risks to a certain extent using financial instruments such as futures trading and options. Most operational risks are caused by institutional voids, and JETRO and others have published examples of how best to deal with them (JETRO 2006). It is possible to forecast these risks to a certain extent, and few have great impact as to cause a cessation of business operations. The most important risk to consider under the global business strategy are risks of policy changes, as we have observed in the sudden order for a company to leave the industrial park in Shanghai's Jiading district. The risk of political instability such as a coup de'état is also great, but unlikely in our emerging nation subjects of China and India (unlike developing nations with huge institutional voids). Election results in India can impact policy direction, and it can be characterized as a policy risk in the broad sense of the term.

So how should companies react in the face of policy risk? These risks exist because of sudden changes in government policy and the breadth of discretion given to governments in the administration of policy. Thus, understanding the direction and breadth of these changes is, in effect, risk management, specifically, it is to recognize the policy objectives and priorities of the national and local governments. 
In China, central and local governments publicize policy decisions made at the various levels. In India, policies change depending on election results at the national and state levels. Gathering and analyzing this kind of intelligence is a necessity. Of the two countries, China carries higher risks because policy making is done by a select number of central and local leaders. On the other hand, it is easier to ascertain the general direction of the country in case of India because issues are visible in election results. However, in either case, building win-win relationships with local governments is critical, as already discussed. Local corporate social responsibility, or CSR, activities are effective responses to societal risks such as opposition to foreign firms in India and anti-Japanese sentiments in China. In any case, companies must realize the necessity for long-term investments in the countries in which they conduct business.

Open Access This chapter is distributed under the terms of the Creative Commons Attribution Noncommercial License, which permits any noncommercial use, distribution, and reproduction in any medium, provided the original author(s) and source are credited.

\section{References}

Aoki, M. (2010). Toward comparative institutional analysis. Tokyo: NTT Publishing Ltd., July 2007 (in Japanese).

Capelli, P., Singh, H., Singh, J., \& Useem, M. (2011). The India way: How India's top business leaders are revolutionizing management. Boston: Harvard Business Press.

Grief, A. (2006). Family structure, institutions and growth: The origins and implications of Western corporations. American Economic Review, 96(2), 308-312.

JETRO. (2006, July). Chugoku business no risk management. Tokyo: Japan External Trade Organization (JETRO) (in Japanese).

Khanna, T. (2007). Billions of Entrepreneurs: How China and India are reshaping their futures and yours. Boston: Harvard Business School Press.

Khanna, T., \& Palpu K. G. (2010). Wining in emerging markets: A roadmap for strategy and execution. Boston: Harvard Business School Press.

North, C. D. (1990). Institutions, institutional change and economic performance. Oxford: Oxford University Press.

Xu, C. (2011). The fundamental institutions of China's reforms and development. Journal of Economic Literature, 49(4), 1076-1151. 